UDC 1/14:7.038.6

Aharon ADIBEKIAN

\title{
THE STRUCTURE OF HUMAN BEING IN POSTMODERN PHILOSOPHY
}

\begin{abstract}
The originality of postmodernism consists in the negation of the intellectual achievements of previous eras and losing the continuity of the problems of human existence, thus, losing the search for its solution. So, it is forced to justify its postulates and methodology by the way of reflection. How can the individual in the case of the negation of philosophical ontology, epistemology and logic make more or less adequate reflection and comparative analysis? Last resort is found in philosophical methodology, which remained beyond criticism of adherents of postmodernism as their different sentences can be considered as a product of detailed methodological postulates. The methodology is veiled by the concept of "discourse", i.e. the characteristics of Postmodernism as a special spiritual attitude and ideological orientation, expressed in "image I" possessing certain connectedness and immersed in a socio-cultural, socio-psychological and other contexts. However, in the postmodernists is implicitly shown the methodological function of philosophy in the formation of the "reflexive consciousness" and "social reflection" as of the two fundamental determinants of human existence in the post-industrial society.
\end{abstract}

Keywords: philosophy of postmodern, structure of human being, reflexive consciousness, methodology.

Postmodernism is a relatively recent phenomenon, and its age is defined in different ways, but it is clear that it is the culture of post-industrial, information society and is represented as a special spiritual state and mentality as a way of life and creation, and, perhaps, the new era of which one will judge in the case of the following era, as it has happened in history. If the adherents of previous epochs are mainly engaged of its implementation of theirs vision of human destination - as a demiurge of social and cultural reality, originality of postmodernism consist in the negation of the achievements of previous eras and losing the continuity of the problems of hu- man existence and thus loses the search for its solution, it is forced to justify its postulates and methodology by the way of self-reflection.

A prerequisite for the criticism of the traditional Western European way of thinking with its "logocentric tradition" is the principle of "decentration" - overcoming the fundamental principle of European cultural consciousness - the principle of "centration" that penetrates virtually all the spheres of intellectual activity of European Human:

- in Gnoseology and Psychology - it leads to a ratiocentrism, the primacy of discursivelogical consciousness over all other 
forms;

- in Cultural Studies - to Eurocentrism, converting the European social practices and mindset in line with the criteria for the assessment of other cultures,

- in History - to futurocentrism emanating from that historic moment is always the "best", "progressive" over the past, and its role - "preparation" of the better and more enlightened epochs in the future;

- in Worldview - to substantialistic reductionism postulating the existence of a certain stationary source entity, which needs embodiment in a particular material;

- in Philosophy - of its view of the subject as a kind of center of semantic irradiation, which "externalizes" in the object;

- in Linguistics - the idea of the primacy of the signified, which fastened by means of the signifier, or primary of the denotation with respect to the connotation;

- in Literary criticism - is the concept of "content", which is preceded by a "form of expression" or the concept of the author's unique "personality", "soul" of which the material otherness is a product;

- in Positivism (in its causal-genetic "mythologeme") - any work has a reason (Derrida, 2000).

The philosophy of postmodernism opposes itself especially Hegel, whose philosophy is based on the categories such as "single, whole", "universal", "absolute", "being", "truth", "reason", "progress", etc., seeing in it the highest point in Western rationalism and logocentrism. In this sense, it is a philosophical movement that can be defined as Anti-Hegelianism, which is leaning towards extreme subjectivism (sub- jectless subjectivism), relativism and pluralism.

The forerunners are of the philosophy of postmodernism is Nietzsche, Heidegger, Weber, Sartre, Camus, etc. The first of them rejected Hegel's systematic way of thinking, opposing his thinking in the form of small fragments, maxims, aphorisms and sententias from the standpoint of extreme nihilism, whit the loss of faith in the mind of man and humanism.

In Sociology - Max Weber with his theory of ideal types, which are distinguished not through inherent social characteristics, and are designed exclusively for research purposes as a tool of knowledge and social management. Heidegger advocated reappraisal and the abandonment of the fundamental concepts of classical philosophy.

For the French existentialists Human is not a manifestation of given essence, but is an individually realized project.

Postmodern philosophy refuses from:

a) the consideration the world as a whole with the unifying center or substance: the world is divided into many pieces, between which there are no stable connections;

b) the category of being, which in previous philosophy was "the last foundation" indisputable credibility of thought and must give place to language - the only being that can be cognized;

c) the concept of truth, revises the previous understanding of knowledge and cognition, it rejects scientism and resonates with agnosticism;

d) from recognition of the man as a subject of activity and knowledge, from anthro- 
pocentrism (man as center of the universe and the purpose of all events in the world) and humanism.

The world including man is perceived as a "chaos" of endless individual phenomena and events which originally reflect in the consciousness of every human being, and the man himself in his singularity and uniqueness of the universe, also is a collection of individual endless manifestations ("individual" here becomes "dividual"), which acts here and now, rather than in the past or in the future (see Derrida, 2000).

The approach of the old philosophy of man as a "universal subject" of knowledge and action, capable in some approximation to understand the essence of life and act according to its rules, is replaced by the task of each individual to form his own vision of the world and of themselves, as well as the "others" in order to ensure their participation in group interaction.

In another approach, the idea of the "death of the subject", according to L. Altyusser follows that man - as a phenomenon in all its complexity of its manifestations and relations with the world - due to the fact that he is already the result of theoretical reflection, not its starting point, is cannot be explanatory principle in the study of a "social whole" (Baudrillard, 2015).

Person or separate human in the postmodern receives two opposing definitions:

1. the person is not the starting point, is a result of the socio-cultural environment, a chaotic reflection of this chaos;

2. the socio-cultural environment itself is composed of chaotic actions of separate persons - the actors of this environment. According to these approaches for Baud- rillard is a simulacra (Simulacrum in Latin the image, likeness) as a results of the process simulation, interpreted it as "a product of hyper-real" using the real models that do not have their own origins and reality.

To be completed or "pure simulacrum" the image passes through a series of successive stages:

1. "it is the reflection of a basic reality;

2. it masks and distorts the basic reality;

3. it masks the absence of a basic reality;

4. it has no relation to any reality;

5. it is its own pure simulacrum" (Furs, 2012).

Under the influence of simulation the "replacement of the real at the signs of this reality" takes place resulting in simulacrum, and which in principle does not correlate with reality directly, if in generally may by correlated with anything, besides with other Simulacres.

Actually, this is the fundamental property of the simulacra.

Thus, the person in the world is a kind of landmark formation which does not have any object correlation and exists only in personal mind.

Since simulacra arises on the basis of cultural and other unconscious (when a person goes through primary socialization stage) and is comprehended in the process of personal formation, the significant role here becomes "everyday life" (or in terms of the post-modernists "quotidian") a set of direct contacts with the environment and the realization of value preferences.

Therefore, the postmodern in sociology and the humanities is designed to redirect the philosophy with traditional issues (dealt mainly by "sub specie aeternitatis" - from the 
"point of view of eternity"), on the problems of everyday life, where most vital processes occur that, usually, escape from rational analysis.

Moreover, according to Bourdieu, each social group is distinguished by its way of life, manners, thinking, feeding; it depends on their own traditions, even when they want to avoid, and group preferences and tastes, even aesthetic, predetermined political and philosophical and other views (Bourdieu, 1993).

The foregoing also applies to the individual, which is unique and inimitable, and in condition of post-industrial society obtained relatively maximum freedom of choice is not only a profession, but a way of life (including gender) and the basis for selection are:

1. "reflective consciousness" (for self-knowledge and self-esteem)

2. "social reflection" (for the understanding and evaluation of the "others").

Lakan formulated and theoretically substantiated the existence of the structure of the human mind as a complex, contradictory interaction of components: the Imaginary, the Symbolic and the Real (Lakan, 2005).

Imaginary - is the set of illusory notions that man creates of himself and which plays an important role in mental protection, or rather, self-defense.

Symbolic - the sphere of social and cultural norms and beliefs that the individual learns mostly unconsciously, to be able to exist normally in this society it.

Real - this is an area generated biologically and psychically sublimated needs and impulses, which not given to the individual consciousness in rationalized form that is accessible for him.

In general terms, we are interested in the meaning of the Symbolism: when a person enters the symbolic kingdom, he finds it in the form of the Father (with his name and prohibitions) and the "third term" of the primary. The basic "human relations" and "others" mean for him an acquaintance with culture as a social and linguistic institution of human existence.

The question arises, as in the denial of philosophical ontology; epistemology and logic can ensure each individual is more or less adequate reflection and comparative analysis?

Last resort - is a philosophical methodology, which remained beyond criticism adherents of postmodernism, because their different sentences are a product of the detailed methodological postulates.

The methodology is veiled by the concept of "discourse" - the characteristics of the postmodernism as a special spiritual attitude and ideological orientations, expressed in the whole "image I" possessing a certain connectedness and immersed in a socio-cultural, socio-psychological and other contexts.

However, in the postmodernists implicitly is shown the methodological function of philosophy in the formation of the two fundamental determinants of human existence in the post-industrial society:

\section{- "reflexive consciousness"}

- "social reflection".

\section{REFERENCES}

Baudrillard, J. (2015). Simulyakry i simulyatsiya (Simulacra and Simulation, in Russian). (A.Kachalova, Trans.). Moscow: Ripol-Classic.

Bourdieu, P. (1993). Sotsiologiya politiki (Sociology of Politic, in Russian). (N.A. 
Shmatko, Trans. and Pref.). Moscow: Socio-Logos.

Derrida, J. (2000). O grammatologii (Of Grammatology, in Russian). Moscow: Ad Marginem.

Furs, V. (2012). Sotsial'no-kriticheskaya filosofiya posle "Smerti Sub'ekta" (So-
cial-Critical Philosophy of the after "Death of the Subject", in Russian). (Works, Vol. 2). Vilnius.

Lakan, J. (2005). Imena-ottsa (Name of the Father, in Russian). (A.Chernoglazova, Trans.). Moscow: Gnosis/Logos. 